\title{
TROPHIC ECOLOGY OF CATS (FELIS CATUS) IN MONTAÑA DE GUAZA: IMPLICATIONS FOR THE CONSERVATION OF THE CRITICALLY ENDANGERED GIANT LIZARD OF TENERIFE (GALLOTIA INTERMEDIA)
}

\author{
Adrián Jesús Flores Ravelo*, Juan Carlos Rando Reyes* \\ Universidad de La Laguna
}

\begin{abstract}
Cats have accompanied humans since they were domesticated, spreading and settling in a large number of islands where they modify environments and prey on native species. In the Canary Islands, several studies have shown that cat's prey on native species, including Critically Endangered species such as the giant lizards of Tenerife (Gallotia intermedia), La Gomera $(G$. bravoana) and El Hierro $(G$. simonyi). This study focuses on the trophic ecology of the cat in Montaña de Guaza, where a population of the giant lizard of Tenerife is located. The current results show important changes in the diet of this alien species at this area in relation to the obtained by others author in 2004. The main changes detected are the low level of consumption of mammals and the high levels of birds and lizards. These changes seem to be a direct consequence of a low density of rabbit (Oryctolagus cuniculus), the main prey at the different habitats of Canary Islands, probably due to the rabbit hemorrhagic disease virus (RHDV) incidence. The high consumption of reptiles detected in this study could explain the reduction of both distribution area and number of giant lizards at this locality.
\end{abstract}

KEYWORDs: conservation, depredation, invasive mammals, islands, native fauna.

ECOLOGÍA TRÓFICA DE LOS GATOS (FELIS CATUS) EN LA MONTAÑA DE GUAZA: IMPLICACIONES PARA LA CONSERVACIÓN DEL LAGARTO GIGANTE DE TENERIFE (GALLOTIA INTERMEDIA), EN PELIGRO DE EXTINCIÓN

\section{RESUMEN}

Los gatos han acompañado al ser humano desde su domesticación, extendiéndose y asentándose en un gran número de islas donde modifican los entornos y depredan sobre especies autóctonas. En Canarias, varios estudios han demostrado que los gatos depredan sobre especies autóctonas, incluyendo especies en peligro crítico como los lagartos gigantes de Tenerife (Gallotia intermedia), La Gomera (G. bravoana) y El Hierro $(G$. simonyi). El presente estudio se centra en la ecología trófica del gato en la montańa de Guaza, donde se localiza una población del lagarto gigante de Tenerife. Los resultados muestran importantes cambios en la dieta de esta especie exótica en esta zona en relación con los obtenidos por otros autores en 2004. Los principales cambios detectados son los bajos niveles de consumo de mamíferos y los altos niveles de aves y lagartos. Estos cambios parecen ser una consecuencia directa de la baja densidad de conejos (Oryctolagus cuniculus), principal presa en los diferentes hábitats de Canarias, probablemente debido a la incidencia del virus de la enfermedad hemorrágica del conejo (RHDV). El elevado consumo de reptiles detectado en este estudio podría explicar la reducción tanto del área de distribución como del número de lagartos gigantes en esta localidad.

Palabras Clave: conservación, depredación, fauna nativa, islas, mamíferos invasores. 


\section{INTRODUCTION}

Since their domestication approximately 9,000 years ago (Vigne et al. 2009), cats (Felis catus) have accompanied humans in their movements, reaching a large number of territories, disturbing the environments in which they settle and preying on native species. This has occurred and has been observed in both continental (Woods et al. 2003; Loss et al. 2013; Woinarski et al. 2017, 2018; Mori et al. 2019) and island territories (Nogales et al. 2006; Bonnaud et al. 2011; Medina et al. 2011, 2014). Island environments are often more vulnerable to biological invasions, as the species that inhabit them are often more vulnerable to alien predators, competitors, pathogens, and parasites. This explains why more than $80 \%$ of bird extinctions and more than $90 \%$ of reptile extinctions since 1600 have occurred on islands, despite representing only $5 \%$ of the planet's emerged land surface (Whittaker \& Palacios 2007). It has been found that cats have been involved in the extinction of at least 33 species of birds, mammals, and reptiles in island environments over the last few centuries (Medina et al. 2014).

In The Canary Islands have been numerous studies on the trophic ecology of this species and on its impact on the native fauna. These studies have shown that cat's diet in the main habitats (xerophilous environments, thermophilus forests, laurel forests, Canary Island pine forests and high mountain scrubland) is based mainly on introduced mammals, which account for more than $77 \%$ of the biomass of the diet (Nogales et al. 2006). Likewise, birds and reptiles are less important in the diet, with their percentage of biomass contributed varying in the different ecosystems. The highest contribution by birds to cat diet was obtained in the thermophilic forest of El Hierro with 8\% (Nogales et al. 1988). On the other hand, the highest contribution of reptiles was $20.9 \%$, obtained in the high mountain scrubland of Tenerife (Nogales et al. 1990).

The total number of species preyed by cats in the Canary Islands is at least 68 (5 mammals, 16 birds, 15 reptiles and 32 invertebrates) (Medina \& Nogales 2009). Of these, all reptiles are endemic, all 16 bird species are endemic or native except for the red-legged partridge (Alectoris rufa). As for invertebrates, most of them are endemic or native. Special mention should be made for endangered species, such as the Gran Canaria blue chaffinch (Fringilla polatzeki) or Tenerife (Gallotia intermedia), La Gomera $(G$. bravoana) and El Hierro $(G$. simonyi) giant lizards. These three species are "Critically Endangered" according to IUCN criteria (IUCN 2021), and in the category of "en Peligro de Extinción" under Spanish and Canary Islands laws.

The distribution of these lizards was wider in the past on each of their respective islands. However, these species currently survive in areas that are difficult to access, of small size, and at times, scarce trophic resources. Predation by cats has

* Universidad de La Laguna. alu0100913859@ull.edu.es.

** Universidad de La Laguna. jcrando@ull.edu.es. Departamento de Biología Animal, Edafología y Geología. 

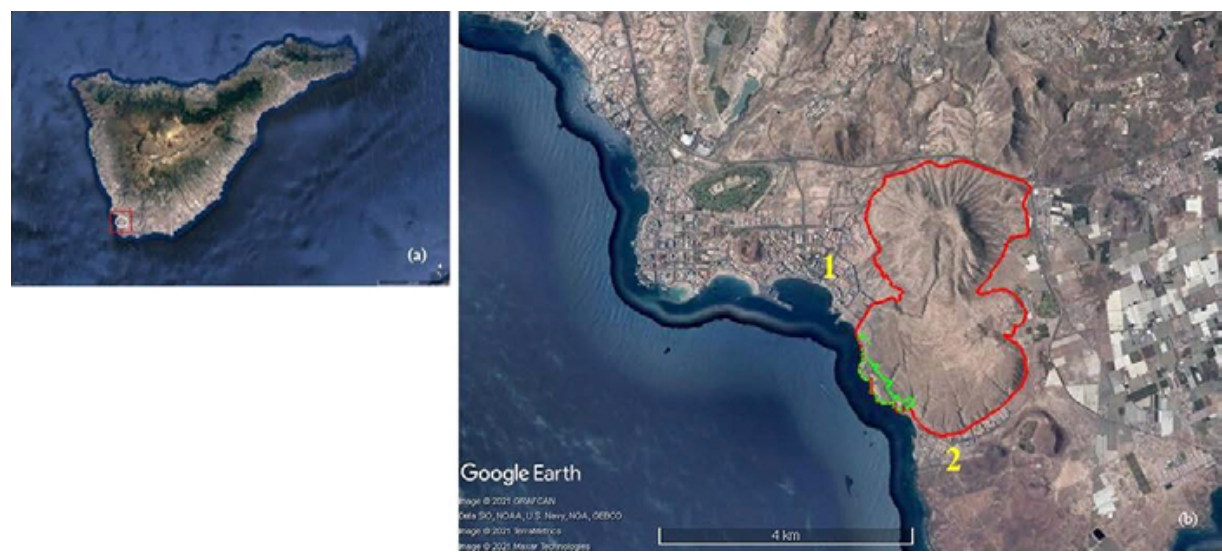

Figure 1. (a): Tenerife Isla and Montaña de Guaza (square); (b): Montaña de Guaza Natural Monument (red) and critical area for Tenerife giant lizard (green) were survive a population of this lizard. The urban areas of Los Cristianos (1) and El Palm-Mar (2) are showed.

been a decisive factor that has led these species to their current situation (GarcíaMárquez et al. 1997; Rando 2002; Afonso \& Mateo 2009). So to know the impact of cats on the last wild populations of these giant reptiles could be a key factor to apply effective conservation action to avoid extinctions. Unlike the giant lizards of El Hierro and La Gomera, which have a single natural population, the giant lizard of Tenerife has two populations $30 \mathrm{~km}$ apart. They are located in the cliffs of Teno and Guaza mountain (Rando et al. 2004), the latter with the highest number of individuals (Ginovés et al. 2005). However, the last population size estimation for the giant lizard of Tenerife (Padilla et al. 2019) showed an important reduction of both distribution area and number of the giant lizards at Montaña de Guaza in relation to previous studies (Ginovés et al. 2005).

The aim of this work is to study the diet of cat in Montaña de Guaza and to compare the current results with those obtained by Ginovés et al. (2004), to know the current impact of cats on one of the last populations of the giant lizard of Tenerife.

\section{MATERIAL AND METHODS}

\section{STUdY AREA}

The study was performed in Montaña de Guaza, located in the southern part of Tenerife between two urban centers, Los Cristianos and El Palm-Mar. According to Canarian Laws this area is a Protected Natural Space under the category of "natual monument" (figure 1).

The climate in this area is characterized by high average temperatures, high insolation, and low rainfall of less than $200 \mathrm{~mm}$ per year (MINCMG 2008). The 
vegetation of this area is conditioned by the rainfall and temperature regime, with a predominance of tabaibal-cardonal species.

Due to anthropogenic action, some species have been introduced into this area, including the Indian prickly pear cactus (Opuntia dilenii), which is widely distributed in the area, and at least, 5 species of introduced mammals, the black rat (Rattus rattus), the house mouse (Mus musculus), the european rabbit (Oryctolagus cuniculus), the algerian hedgehog (Atelerix algirus) and the cat (Felis catus) (MINCMG 2008, Nogales et al. 2006)

This area hosts a population of the Tenerife giant lizard in its cliff area and adjacent ravines. This area, occupied by the giant lizard, was declared as a "critical area" for the conservation in the recovery plan for this species (Decreto 230/2017, de 20 de noviembre, por el que se aprueba el Plan de Recuperación del Lagarto Gigante de Tenerife Gallotia intermedia; BOC 229 de 20.11.2017). These shore cliffs are also home to colonies of seabirds such as yellow-legged gulls (Larus michahellis), Bulwer's petrel (Bulweria bulwerii) and Cory's shearwater (Calonectris borealis) (Martín \& Lorenzo 2001).

\section{SAMPLING AND IDENTIFICATION}

A total of three surveys were carried out (December 2019, January, and February 2020) by visually locating the scats on the ground, most of which were found in the ravine beds. Each scats group was geo-referenced, collected and labelled for transport to the laboratory. Scats were collected both inside the critical area and outside, in order to clarify possible differences in diet between these areas.

Subsequently, scats were broken up in the laboratory to extract the prey remains, such as bones, feathers, scales, and hair, and to make a comparison with specimens conserved in the vertebrate collection of the Departmento de Biología Animal, Edafología y Geología of La Laguna University (DZUL) using a binocular magnifying glass $(16 \times)$ in order to identify the species.

The minimum number of individuals was calculated for those samples with more than one individual of the same species in a group of scats, based on the identification of repeated anatomical elements. Invertebrates were not considered when characterizing the diet due to their low weight and because indirect prey could not be ruled out.

\section{Data ANALYSIS}

To calculate the biomass of each prey in the diet, the weights shown in table 1 were assigned. For large prey such as rabbits (Oryctolagus cuniculus), pigeons (Columba livia), and gulls (Larus michahellis), which have a biomass greater than the daily intake of the cats, the biomass applied was $170 \mathrm{~g}$, following the criteria of previous works (Medina et al. 2010; Fitzgerald \& Karl 1979). 


\section{TABLE 1. WEIGHT ASSIGNED TO EACH SPECIES}

\begin{tabular}{lcl}
\multicolumn{1}{c}{ Stecies } & Weight (GRAMS) & \multicolumn{1}{c}{ Reference } \\
\hline Rattus rattus & 84,5 & Rando \& López 2001 \\
\hline Mus musculus & 18,5 & Blanco et al. 1998 \\
\hline Tarentola delalandii & 6,5 & Nogales \& Medina 1996 \\
\hline Oryctolagus cunniculus & 170 & Average maximum intake of a cat (Fitzgerald \& Karl, 1979) \\
\hline G. galloti & 21,5 & Our data \\
\hline G. intermedia & 69 & Albaladejo 2014 \\
\hline Columba livia & 170 & Average maximum intake of a cat (Fitzgerald \& Karl, 1979) \\
\hline Bulweria bulweri & 99 & Dunning 2008 \\
\hline Anthus berthelotii & 16 & Dunning 2008 \\
\hline Bucanetes githagineus & 19,6 & Dunning 2008 \\
\hline Sylvia sp. & 10 & Dunning 2008 \\
\hline Larus michahellis & 170 & Average intake of a cat (Fitzgerald \& Karl, 1979) \\
\hline
\end{tabular}

In order to detect possible variations in cat diet over time, the samples obtained within the critical area were compared with the data obtained by Ginovés et al. (2005). These authors collected their samples inside this critical area or very close to it.

The parameters calculated from the results of the analyses were: number of individuals of each species, total biomass consumed, total weight contributed by each species, frequency of occurrence of each prey $(\mathrm{F})$, percentage of each prey $(\mathrm{N})$ and the percentage of biomass contributed by each prey (W). The index of relative importance (IRI) was also calculated for each dietary category.

On the other hand, the standardized Levins niche breadth index (B) was calculated based on the prey percentage, and the overlap between the diets of the two studied areas and between the current diet and the one obtained in 2004 (Ginovés et al. 2005) was analyzed by calculating the Morisita similarity index (C) (Krebs 1989) based on the prey percentage. All calculations were performed using Microsoft Excel.

Finally, a chi-square test $\left(\chi^{2}\right)$ was performed using the "Past326b" program (Hammer et al. 2001) in order to detect possible differences in the consumption of the prey items between the two areas and data from 2004 (Ginovés et al. 2005).

\section{RESULTS}

The total number of samples collected was 77,57 from the inside of the critical area (figure 2) and 20 from the outside (figure 3). Seven samples were excluded from the study due to the impossibility of identifying any remains. A total 


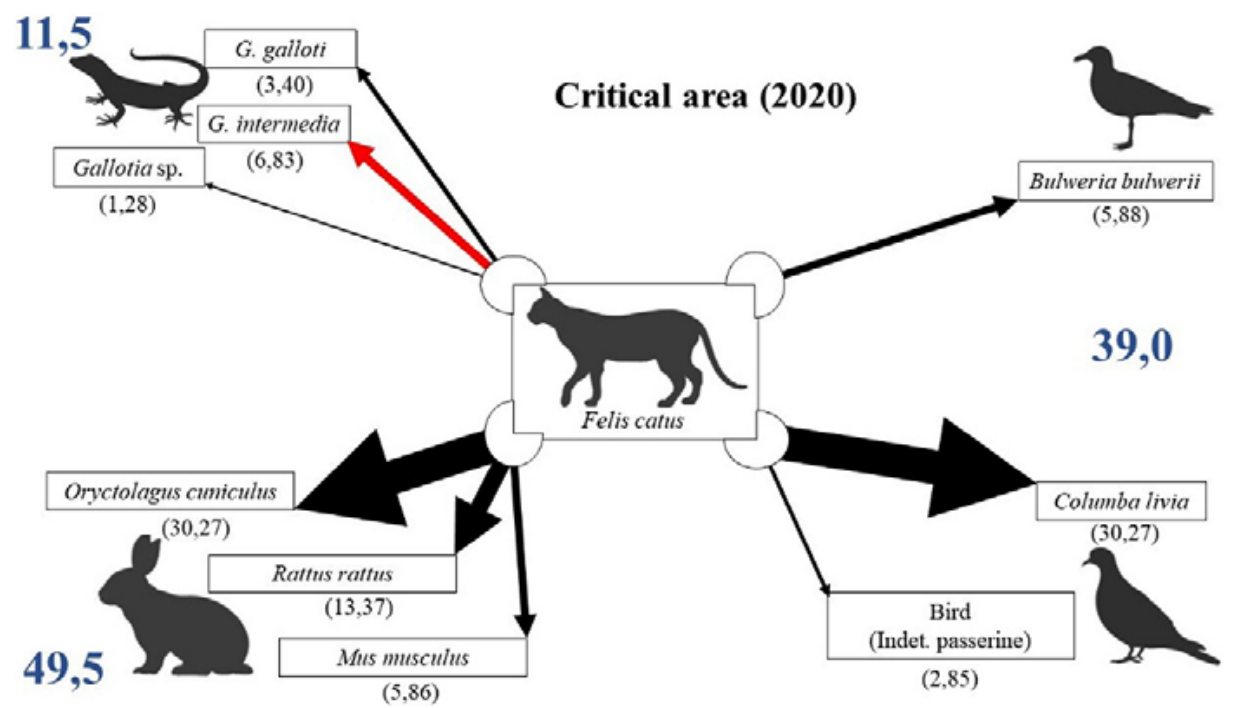

Figure 2. representation of the percentage of biomass contributed by each prey inside the critical area. In blue, the percentage of total biomass contributed by each group (mammals, birds, and reptiles). The percentage of biomass contributed by each species is shown in brackets.

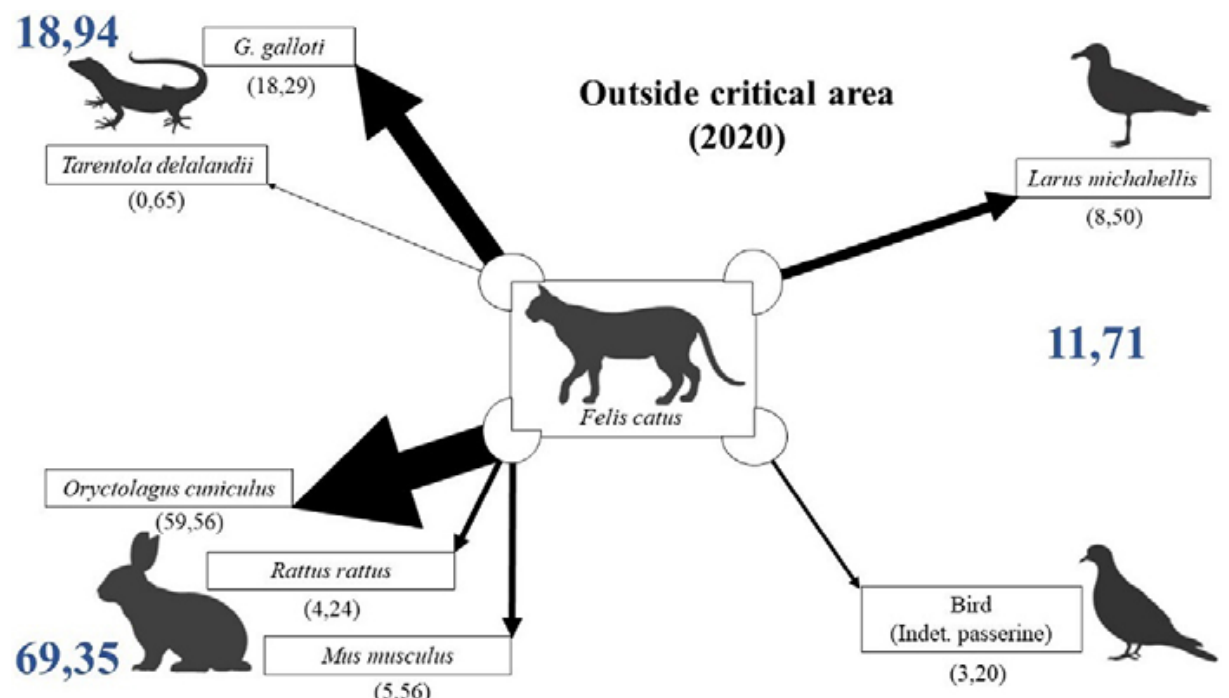

Figure 3. representation of the percentage of biomass contributed by each prey outside the critical area. In blue, the percentage of total biomass contributed by each group (mammals, birds, and reptiles). The percentage of biomass contributed by each species is shown in brackets. 


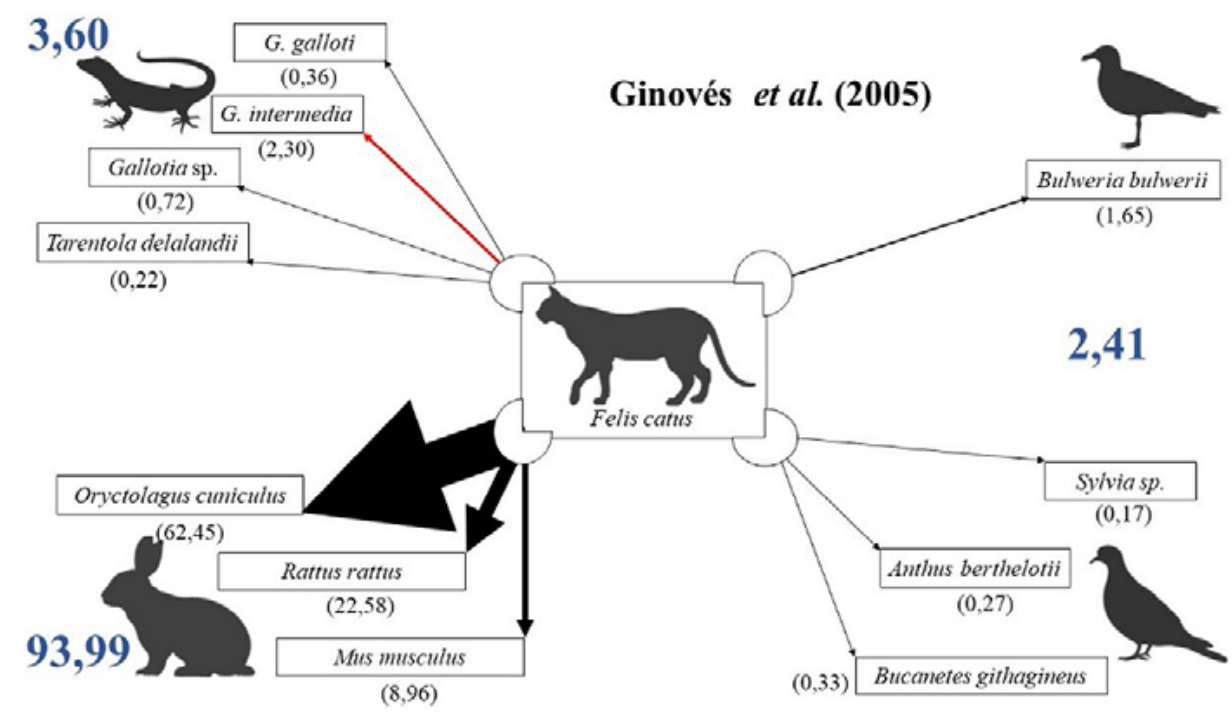

Figure 4. representation of the percentage of biomass contributed by each prey in 2004 (Ginovés et al. 2005). In blue, the percentage of total biomass contributed by each group (mammals, birds, and reptiles). The percentage of biomass contributed by each species is shown in brackets.

of 70 samples were analyzed, 51 from inside the critical area and 19 from outside. In addition, 36 samples of Ginovés et al. (2005) were included in the analyses (figures 4 and 5).

\section{Critical area}

The data from the critical area (table 2) show that mammals are the most important in terms of total individuals preyed, index of relative importance and biomass, being a $49.5 \%$ of the total biomass of the diet. Among the mammals, house mice (M. musculus) are the most numerous preys, followed by the European rabbit (O.cuniculus) and the black rat ( $R$. rattus). Birds are the second most important group, contributing $38.99 \%$ of the biomass of the diet. In this group, the rock dove (C. livia) stands out, contributing $30.27 \%$ of the biomass, very similar to that contributed by rabbits. In addition, 3 Bulwer's petrels $(B$. bulwerii) and 9 passerines that could not be identified to species level were also detected. Reptiles are the group with the lowest biomass contribution with $11.5 \%$. In this group, a minimum of 5 specimens of the Tenerife giant lizard (G. intermedia) (6.83\% of the total biomass) and 8 Tenerife common lizards (G. galloti) (3.40\% of the total biomass) were detected. The bones identified as Gallotia sp. correspond to individuals that could not be clearly assigned to either of the two species mentioned (figure 2, 5 and 6). 


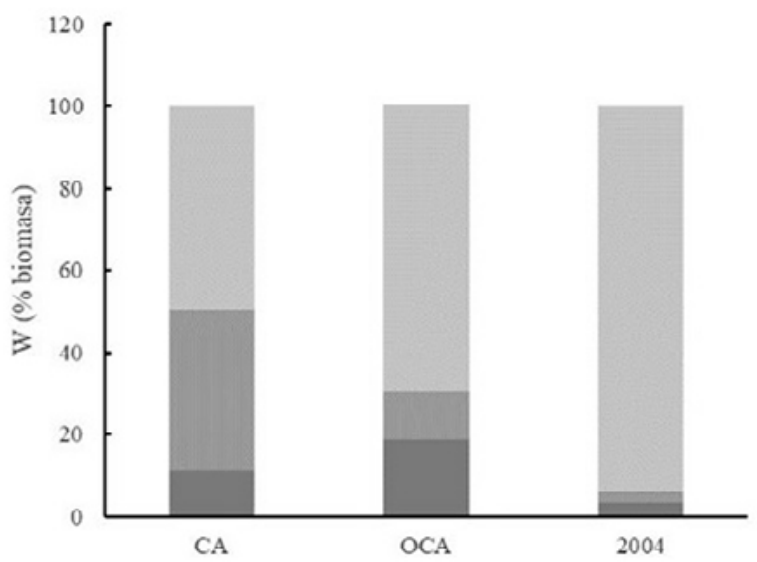

= Mammals

m Birds

neptiles

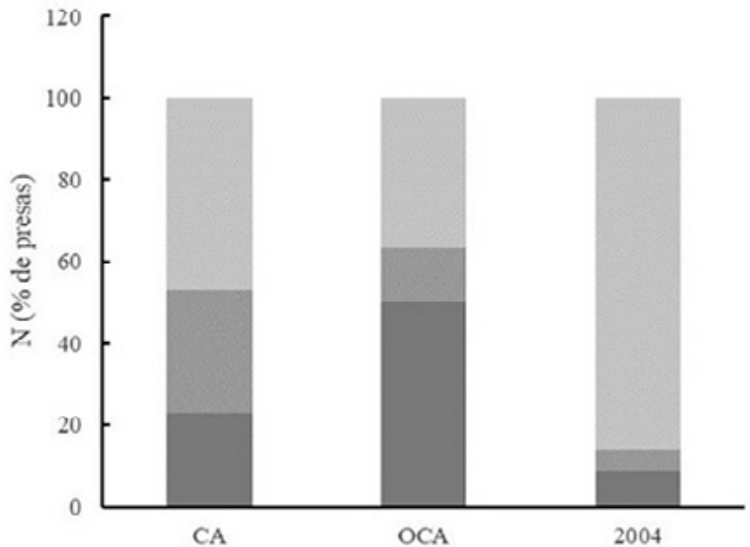

m Mammals

B Birds

= Reptiles

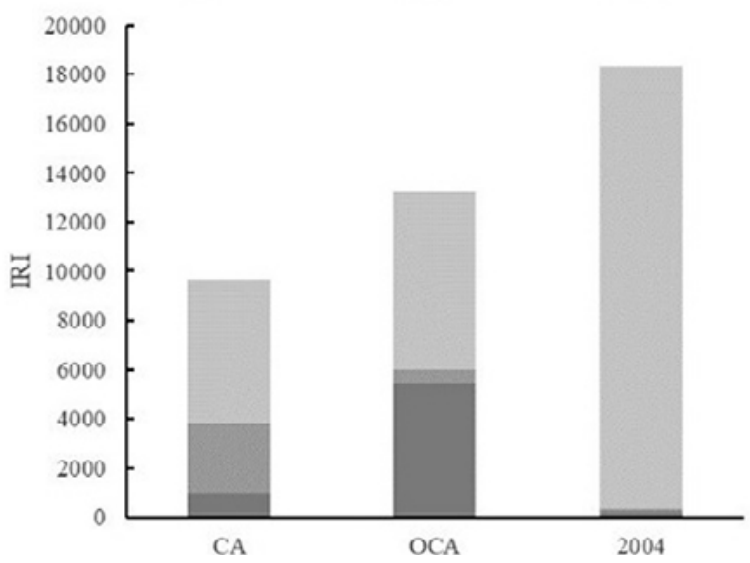

= Mammals

$m$ Birds

$=$ Reptiles

Figure 5. Comparison of the percentage of biomass contribution by each prey (W), percentage of prey $(\mathrm{N})$ and index of relative importance for each group studied.

CA: critical area. OCA: outside of the critical area.

2004: results obtained from the data of Ginovés et al. (2005). 


\begin{tabular}{|c|c|c|c|c|c|c|}
\hline \multicolumn{7}{|c|}{$\begin{array}{l}\text { TABLE 2. DATA FROM THE SAMPLES OBTAINED IN THE CRITICAL } \\
\text { AREA IN MONTAÑA DE GUAZA }\end{array}$} \\
\hline Prey & MNI & Total Weight & W & $\mathrm{F}$ & $\mathrm{N}$ & IRI \\
\hline TOTAL REPTILES & 16 & 581,5 & 11,50 & 27,44 & 22,86 & 943,13 \\
\hline G. galloti & 8 & 172,0 & 3,40 & 11,76 & 11,43 & 174,50 \\
\hline Gallotia sp. & 3 & 64,5 & 1,28 & 5,88 & 4,29 & 32,73 \\
\hline G. intermedia & 5 & 345,0 & 6,83 & 9,80 & 7,14 & 136,86 \\
\hline TOTAL BIRDS & 21 & 1971,0 & 38,99 & 41,18 & 30,01 & 2841,62 \\
\hline Bird (indet. passerine) & 9 & 144,0 & 2,85 & 17,65 & 12,86 & 277,26 \\
\hline Columba livia & 9 & 1530,0 & 30,27 & 17,65 & 12,86 & 761,25 \\
\hline Bulweria bulwerii & 3 & 297,0 & 5,88 & 5,88 & 4,29 & 59,78 \\
\hline TOTAL mammaLs & 33 & 2502,0 & 49,50 & 60,79 & 47,15 & 5875,38 \\
\hline Oryctolagus cuniculus & 9 & 1530,0 & 30,27 & 17,65 & 12,86 & 761,25 \\
\hline Rattus rattus & 8 & 676,0 & 13,37 & 15,69 & 11,43 & 389,18 \\
\hline Mus musculus & 16 & 296,0 & 5,86 & 27,45 & 22,86 & 788,26 \\
\hline TOTAL & 70,00 & 5054,5 & 100 & & 100 & \\
\hline
\end{tabular}

MNI: Minimum numbers of individuals; W: Biomass \%: F: Frequency of occurrence; N: Percentage of prey; IRI: Index of relative importance.

\section{OUTSIDE THE CRITICAL AREA}

On the other hand, outside the critical area (table 3), a greater importance of mammals in the diet is observed (69.35\% of the total biomass), followed by reptiles. Among the mammals, rabbits predominate, accounting for $18.42 \%$ of the prey and contributing $59.56 \%$ of the diet biomass. Reptiles accounted for $50 \%$ of the preys (17 Tenerife common lizards ( $G$. galloti) and two Tenerife gecko (Tarentola delalandii) and contributed $18.94 \%$ of the biomass of diet in this area. The last group in importance in this area were birds, with 4 passerines and 1 yellow-legged gull (L. michahellis). This group contributes $11.71 \%$ of the biomass to the diet of the cat (figure 3, 5 and 6).

The Diet of THE CAT IN 2004 vs. 2020

The same parameters calculated for the current samples were obtained from data obtained by Ginovés et al. (2005) in the year 2004 (table 4). That year, the importance of mammals in the diet was high (93.99\% of the total biomass), with the European rabbit (O. cuniculus) accounting for $62.45 \%$ of the total biomass of the diet. Birds and reptiles accounted for $2.41 \%$ and $3.6 \%$ respectively. As far as the Tenerife giant lizard is concerned, in 2004 they represented $2.3 \%$ of the total biomass of the cat's diet (figure 4 and 5). 

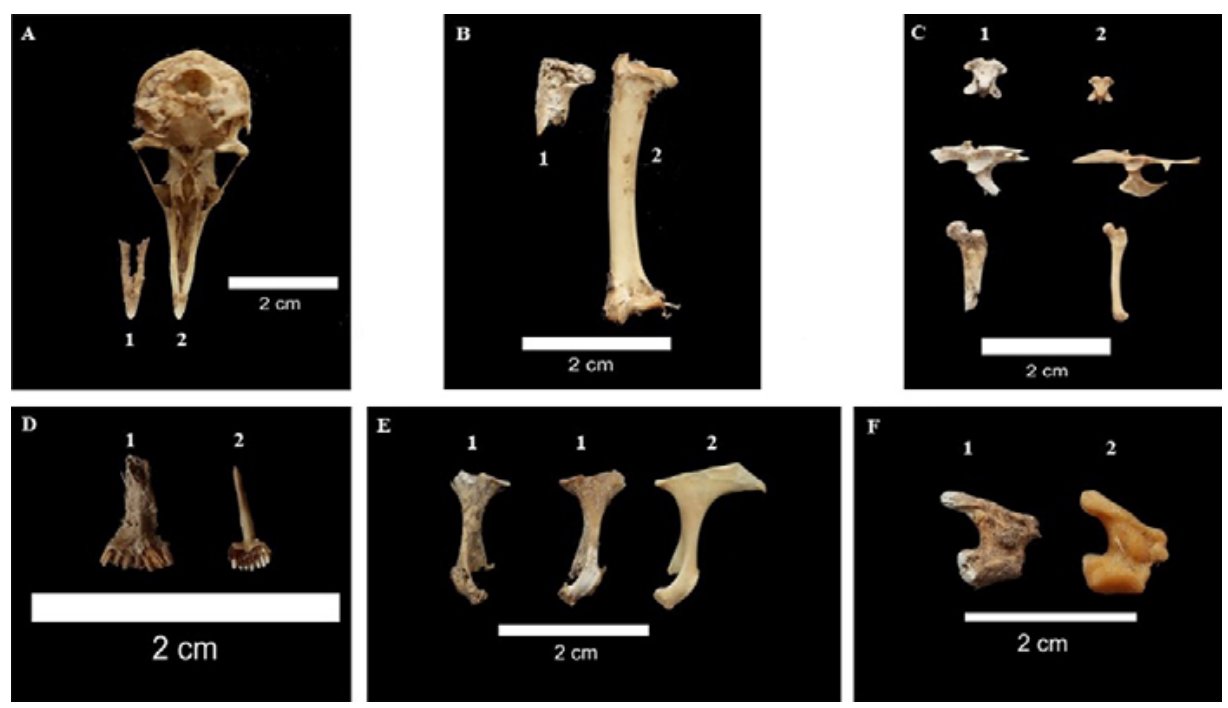

Figure 6. Bone remains found in cat scats from Montaña de Guaza (A1-F1). A-B rock pigeon (Columba livia), A1 fragment of premaxilar, A2 reference skull (DZUL 1061), B1 proximal fragment of femur, B2 reference femur (DZUL 1061); C1-D1 giant lizard of Tenerife (Gallotia intermedia), C1 (from top to bottom) vertebra, fragment of pelvic girdle and proximal fragment of femur, D1 premaxilar, C2-D2 Tenerife common lizard (G. galloti) reference specimen (DZUL 2792), C2 vertebra, fragment of pelvic girdle and proximal fragment of femur, D2 premaxilar; E1 coracoids of Bulwer's petrel (Bulweria bulwerii), E2 referemce specimen (DZUL 393); F carpo ulnar bones of yellow-legged gull (Larus michahellis), F2 reference specimen (DZUL 2877).

\begin{tabular}{|c|c|c|c|c|c|c|}
\hline \multicolumn{7}{|c|}{$\begin{array}{l}\text { TABLE 3. DATA FROM THE SAMPLES OBTAINED OUTSIDE } \\
\text { THE CRITICAL IN MONTANAA DE GUAZA }\end{array}$} \\
\hline Prey & MNI & TOTAL WEIGHT & W & $\mathrm{F}$ & $\mathrm{N}$ & IRI \\
\hline Total reptiles & 19 & 378,5 & 18,94 & 78,95 & 50,00 & 5442,81 \\
\hline G. galloti & 17 & 365,5 & 18,29 & 73,68 & 44,74 & 4643,82 \\
\hline T. delalandii & 2 & 13,0 & 0,65 & 10,53 & 5,26 & 62,27 \\
\hline TOtAL BIRDS & 5 & 234,0 & 11,71 & 21,05 & 13,16 & 523,47 \\
\hline Bird (indet. passerine) & 4 & 64,0 & 3,20 & 21,05 & 10,53 & 288,94 \\
\hline Larus michahellis & 1 & 170,0 & 8,51 & 5,26 & 2,63 & 58,60 \\
\hline TOTAL MAMMALS & 14 & 1385,5 & 69,35 & 68,42 & 36,84 & 7265,66 \\
\hline Oryctolagus cuniculus & 7 & 1190,0 & 59,56 & 36,84 & 18,42 & 2872,82 \\
\hline Rattus rattus & 1 & 84,5 & 4,23 & 5,26 & 2,63 & 36,09 \\
\hline Mus musculus & 6 & 111,0 & 5,56 & 31,58 & 15,79 & 674,22 \\
\hline TOTAL & 38 & 1998,0 & 100 & & 100 & \\
\hline
\end{tabular}

MNI: Minimum numbers of individuals; W: Biomass \%: F: Frequency of occurrence; N: Percentage of prey; IRI: Index of relative importance. 


\begin{tabular}{|c|c|c|c|c|c|c|}
\hline Prey & MNI & TOTAL Weight & W & $\mathrm{F}$ & $\mathrm{N}$ & IRI \\
\hline TOTAL REPTILES & 7 & 215,5 & 3,60 & 19,44 & 8,97 & 244,39 \\
\hline G. galloti & 1 & 21,5 & 0,36 & 2,77 & 1,28 & 4,53 \\
\hline Gallotia sp. & 2 & 43,0 & 0,72 & 5,55 & 2,57 & 18,22 \\
\hline G. intermedia & 2 & 138,0 & 2,30 & 5,55 & 2,57 & 27,03 \\
\hline T. delalandii & 2 & 13,0 & 0,22 & 5,55 & 2,57 & 15,44 \\
\hline TOTAL BIRDS & 4 & 144,6 & 2,41 & 11,11 & 5,11 & 83,59 \\
\hline Anthus berthelotii & 1 & 16,0 & 0,27 & 2,77 & 1,28 & 4,28 \\
\hline Bucanetes githagineus & 1 & 19,6 & 0,33 & 2,77 & 1,28 & 4,44 \\
\hline Bulweria bulwerii & 1 & 99,0 & 1,65 & 2,77 & 1,28 & 8,12 \\
\hline Sylvia sp. & 1 & 10,0 & 0,17 & 2,77 & 1,28 & 4,00 \\
\hline TOTAL MammaLS & 67 & 5628,5 & 93,99 & 100,00 & 85,92 & 17990,49 \\
\hline Oryctolagus cuniculus & 22 & 3740,0 & 62,45 & 61,11 & 28,22 & 5540,79 \\
\hline Rattus rattus & 16 & 1352,0 & 22,58 & 41,66 & 20,52 & 1795,45 \\
\hline Mus musculus & 29 & 536,5 & 8,96 & 58,33 & 37,18 & 2691,23 \\
\hline TOTAL & 78 & 5988,6 & 100 & & 100 & \\
\hline
\end{tabular}

MNI: Minimum numbers of individuals; W: Biomass \%: F: Frequency of occurrence; N: Percentage of prey; IRI: Index of relative importance.

The values obtained for the standardized Levins index (B) reflect a poorly specialized diet inside the critical area (0.83), while those obtained outside (0.44) and in 2004 (0.39) show greater dietary specialization. Whereas the standardized Morisita index shows notable differences when comparing the inside and outside of the critical area (0.005), as well as the inside of the critical area in 2020 and in 2004 (0.008).

Likewise, Chi2 test results (table 5) show significative differences in the number of reptiles $\left(\chi^{2}=8.28 ; \mathrm{df}=4 ; \mathrm{p}=0.004\right)$ and, in particular, in number of predated lizards $\left(\chi^{2}=10.8 ; \mathrm{df}=4 ; \mathrm{p}=0.001\right)$ between the inside and outside of the critical area.

When this test was carried out with the data from the critical area at present and those obtained in 2004 (table 6), significative differences were obtained in the total number of reptiles depredated $(\chi 2=5.41 ; \mathrm{df}=4 ; \mathrm{p}=0.0229), G$. galloti $\left(\chi^{2}=6.06 ; \mathrm{df}=4 ; \mathrm{p}=0.0138\right)$, total birds $(\chi 2=16.25 ; \mathrm{df}=4 ; \mathrm{p}=0.0001)$, total mammals $\left(\chi^{2}=25.28 ; \mathrm{df}=4 ; \mathrm{p}=0.0001\right)$ and European rabbit $($ O. cuniculus $)\left(\chi^{2}=\right.$ $5.2 ; \mathrm{df}=4 ; \mathrm{p}=0.022)$. 


\begin{tabular}{|c|c|c|}
\hline \multicolumn{3}{|c|}{$\begin{array}{l}\text { TABLE 5. CHI }{ }^{2} \text { TEST RESULTS OF DIET COMPARISON BETWEEN OUTSIDE } \\
\text { AND INSIDE THE CRITICAL AREA }\end{array}$} \\
\hline Species & $\mathrm{CHI}^{2}$ & p Value \\
\hline Total reptiles & 8,28 & $0,004^{* *}$ \\
\hline G. galloti & 10,80 & $0,001^{* *}$ \\
\hline Total birds & 3,82 & 0,051 \\
\hline Passeriformes & 0,13 & 0,7222 \\
\hline B. bulwerii & 1,67 & 0,1956 \\
\hline Total mammals & 1,06 & 0,303 \\
\hline O. cuniculus & 0,60 & 0,437 \\
\hline R. rattus & 2,49 & 0,1142 \\
\hline M. musculus & 0,76 & 0,3838 \\
\hline
\end{tabular}

\section{DISCUSSION}

Critical area

Previous data from the main ecosystems of the Canary Islands showed that the diet of feral cats consisted essentially of mammals, with birds and reptiles playing a less important role depending on their abundance (Nogales \& Medina 2009). Data obtained in Montaña de Guaza in 2004 (Ginovés et al. 2005) fit this pattern, but important changes in the cat's trophic ecology have now been revealed in this locality. The present data shows significative variations within the critical area between 2004 and today, with the mammalian biomass contribution to the diet having been reduced from $93.99 \%$ to $49.5 \%$, the lowest value recorded to date in the Canary Islands (Nogales \& Medina 2009; Piquet et al. 2019). The mammals decline is particularly focused on the rabbit (O. cuniculus) (figures 2, 4 and 5).

Reptiles and birds have increased their importance compared to 2004. Reptiles have gone from accounting for $3.6 \%$ to $11.5 \%$ of the biomass contributed to the diet. The Tenerife giant lizard ( $G$. intermedia) shows no significant differences; however, it has gone from accounting for $2.57 \%$ of its prey and contributing $2.3 \%$ of biomass to the diet in 2004 to $7.14 \%$ and $6.83 \%$ respectively at present. As for birds, they have gone from contributing $2.41 \%$ to $39 \%$ of the total biomass of the diet, which is the highest value in the studies carried out to date in the Canary Islands. These changes are also reflected in the values obtained for the standardized Levins index, which shows a more specialized diet in 2004 (0.39) than today $(0.83)$. 


\begin{tabular}{|c|c|c|}
\hline \multicolumn{3}{|c|}{$\begin{array}{c}\text { TABLE 6: } \text { CHI }^{2} \text { TEST RESULTS OF COMPARISON BETWEEN CURRENT DIET } \\
\text { AND THOSE OF } 2004 \text { (GINOVÉS ET AL., 2005) }\end{array}$} \\
\hline Species & $\mathrm{CHI}^{2}$ & $\rho$ Value \\
\hline Total reptiles & 5,41 & $0,0229^{*}$ \\
\hline G. galloti & 6,06 & $0,0138^{*}$ \\
\hline G. intermedia & 1,7 & 0,19 \\
\hline Total Birds & 16,25 & $0,0001^{* *}$ \\
\hline Passeriformes & 4.02 & $0.045^{*}$ \\
\hline B. bulwerii & 1,27 & 0,261 \\
\hline TOTAL MAMMALS & 25,28 & $0,0001^{* *}$ \\
\hline O. cuniculus & 5,25 & $0,022^{*}$ \\
\hline R. rattus & 2,24 & 0,1344 \\
\hline M. musculus & 3,58 & 0,0586 \\
\hline
\end{tabular}

* Significant differences.

** Highly significative differences.

\section{Outside THE CRITICAL AREA}

Compared with current data from inside the critical area, an increase in the importance of mammals and a decrease in the importance of birds was observed outside the critical area. However, significant differences were only observed in the consumption of reptiles. This increase in reptile consumption may be due to the reduced presence of birds in the inland ravines of this area. It is worth noting that the consumption of birds in this area is the second highest of those recorded in the Canary Islands, only behind those recorded in the interior of the critical area in this study. Mammal consumption is the second lowest of those recorded to date, behind only that obtained within the critical area in the present study. The standardized Levins index shows a moderately specialized diet (0.44).

\section{DIETARY CHANGES AND IMPLICATIONS FOR THE CONSERVATION OF THE GIANT LIZARD}

The changes observed in the diet between 2004 and 2020 show a decrease in the consumption of mammals, especially rabbits, (Ginovés et al. 2005). These changes may be due to the general decline in rabbit populations in Tenerife (Nadal 2020), which may be caused by the high prevalence of rabbit hemorrhagic fever virus (RHDV) and the presence of its new variant RHDV2 on the island (Foronda et al. 2017). Other studies have found declines of approximately 75\% of the rabbit population due to this virus in some areas of the Iberian Peninsula (Delibes-Mateos et al. 2014). On the other hand, the generalist predator nature 
of the cat allows it to consume a wide variety of prey depending on their availability and abundance in the environment (Fitzgerald \& Turner 2000; Nogales \& Medina 2009), which could explain the increased consumption of birds and reptiles detected in this study.

The data obtained in the present study show that reptiles are the least important group in the cat's diet. However, the increase in importance observed in relation to 2004 may have important implications for the conservation of the population of the Tenerife giant lizard (G. intermedia) that survives in this locality. Latest census of the population of this giant lizard shows a decrease in the number of individuals of this species from 884-1100 estimated by Ginovés et al. (2005) to 359-587 estimated by Padilla et al. (2019) in Montaña de Guaza. Moreover, it has been observed that this decline is not homogeneous, decreasing considerably in the populations located in the ravines that penetrate towards the interior of this locality, which are more accessible to cats, being the main part of the lizard population in the more inaccessible marine cliff of this locality. To confirm this decrease, these authors indicate that it is necessary to repeat this census with a similar methodology in the appropriate season (Padilla et al. 2019).

Food webs in Guaza integrates trophic relations between native and alien species, so the reduction in number of some of them (i.e. one alien species) could have negative impacts on the native (Zavaleta et al. 2001; Courchamp et al. 2002). So The reduction of the European rabbit, an invasive species, seems to be having a negative effect on a native and endangered species such as the Tenerife giant lizard (G. intermedia) in this locality.

Likewise, it has been shown that domestic cats with access to the environment can easily exceed a range of $1 \mathrm{~km}$ (Turner \& Bateson 2000). Therefore, considering the proximity of the urban centers of Los Cristianos and El Palm-Mar, it is not possible to rule out that some of the samples analyzed correspond to stray cats that frequent these urban centers or even domestic cats with access to the environment. In this way, remains of rubbish (plastic or glass fragments) were found in 5 of the samples analyzed, which could indicate that these animals have fed on rubbish in the aforementioned urban centers (figure 1).

These results calls for a better managements of cats to try to ensure the survival of the giant lizard of Tenerife in Montaña de Guaza. To reduce free roaming cats in the close urban areas of Los Cristianos and El Pal-Mar through calls to cat owners for a better control of their pets, and the prohibitions of feed cat at the public spaces are necessary. In addition, a better monitoring of the population of giant lizard on this locality and carry out some actions (i.e. control of feral and free roaming cats, and fenced at least a part of this population) are necessary to avoid the extinction of this giant lizard population.

By other hand, given the wide distribution of cats and rabbits (their most important prey) in the Canary Islands, it is likely that the dietary changes reported in this study have occurred in other areas where rabbits have experienced declining in their populations. For this reason, further studies on the current diet of cats are necessary, especially in localities hosting endangered species. 


\section{ACKNOWLEDGMENT}

We thank to Área de Medio Ambiente del Cabildo de Tenerife and its personal. This paper is the Master's Dissertation of the first author that coursed the master "Biodiversidad terrestre y conservación en islas" in the University of La Laguna, Canary Islands.

RECiBIDO: junio de 2021, ACEPTADo: octubre de 2021 


\section{REFERENCES}

Afonso, O. and Mateo, J.A. 2009. Depredación por gatos de Lagartos Gigantes de La Gomera Gallotia bravoana (Sauria; Lacertidae). Bol. Asoc. Herpetol. Esp., 20: 107-110.

Albaladejo, G. 2014. Caracterización de la población del lagarto canario moteado, Gallotia intermedia, en el Espacio Natural Protegido de la Montańa de Guaza (Tenerife) [Maste final project]. University of La Laguna. $35 \mathrm{pp}$.

Blanco, J.C. 1998. «Ratón casero o doméstico», pp. 209-214. En Mamiferos de España II: cetáceos, artiodáctilos, roedores y lagomorfos de la Península Ibérica, Baleares. Geoplaneta, Barcelona.

Bonnaud, E., Medina, F., Vidal, E., Nogales, M., Tershy, B., Zavaleta, E., Donlan, C.J., Keitt, B., Le Corre, M. and Horwath, S.V. 2011. The diet of feral cats on islands: a review and a call for more studies. Biol. Invasions, 13: 581-603.

Courchamp, F., Chapuis, J. and Pascal, M. 2003. Mammal invaders on islands: impact, control and control impact. Biol. Rev., 78: 347-383.

Delibes-Mateos, M., Ferreira, C., Carro, F., Escudero, M.A. and Gortazar, C. 2014. Ecosystem effects of variant rabbit hemorrhagic disease vírus, Iberian Peninsula. Emerg. Infec. Dis., 20 (12): 20166-2168.

Dunning Jr, J. 2008. CRC Handbook of Avian Body Masses. Boca Raton: CRC Press. 672 pp.

Fitzgerald, B.M. and Karl, B.J. 1979. Foods of feral house cats (Felis catus L.) in forest of the Orongorongo Valley, Wellington. New Zealand Journal of Zoology, 6: 107-126.

Fitzgerald, B.M. and Turner, B.M. 2000. Hunting behaviour of domestic cats and their impact on prey popilations. In: Turner, D.C. and Bateson, P., editors. The domestic cat: the biology of its behaviour, $2^{\text {nd }}$ edition. Cambridge: Cambridge University Press. pp. 151-175.

Foronda, P., Valladares, B., Martín, N., García, K. and Martín, A. 2017. Estudio de patógenos que afectan al conejo silvestre en Tenerife. Obstetrics and Gynaecology, Paediatrics, Preventive Medicine and Public Health, Toxicology, Legal and Forensic Medicine and Parasitology Department. University of La Laguna. 55 pp.

García-Márquez, M., López-Jurado, L. and Mateo, J. 1997. Predación de Gallotia simonyi por gatos cimarrones. Bol. Asoc. Herpetol. Esp., 8: 20-23.

Ginovés, J., Betoret, A. and Martín, A. 2005. Estudio de la población del lagarto gigante de Tenerife (Gallotia intermedia) en el Espacio Natural Protegido de la Montańa de Guaza. Animal Biology Department (zoology). University of La Laguna. 126 pp.

Hammer, Ø., Harper, D.A.T., Ryan, P.D. 2001. «PAST: Paleontological statistics software package for education and data analysis». Palaeontologia Electronica 4(1): 9pp.

Krebs, C.J. 1989. Ecological methodology. New York: Harper and Row Publishers Inc. 654 pp.

Loss, S., Will, T. and Marra, P. 2013. The impact of free-ranging domestic cats on wildlife of the United States. Nat. Commun., 4: 1396.

Martín, A. and Lorenzo, J.A. 2001. Aves del archipiélago canario. La Laguna. Francisco Lemus Editor. 787 pp.

Medina, F. and Nogales, M. 2009. A review on the impacts of feral cats (Felis silvestris catus) in the Canary Islands: implications for the conservation of its endangered fauna. Biodivers. Conserv., 18: 829-846. 
Medina, F., Oliveira, P., Menezes, D., Teixeira, S., García, R. and Nogales, M. 2010. Trophic habits of feral cats in the high mountain shrublands of the Macaronesian islands (NW Africa, Atlantic Ocean). Acta Theriologica, 55: 241-250.

Medina, F., Bonnaud, E., Vidal, E., Tershy, B., Zavaleta, E., Donlan, C.J., Keitt, B., Le Corre, M., Horwath, S.V. and Nogales, M. 2011. A global review of the impacts of invasive cats on island endangered vertebrates. Glob. Chang. Biol., 17: 3503-3510.

Medina, F., Bonnaud, E., Vidal, E. and Nogales, M. 2014. Underlying impacts of invasive cats on islands: not only a question of predation. Biodivers. Conserv., 23: 327-342.

(MINCMG 2008). Gobierno de Canarias, Consejería de Medio Ambiente y Ordenación Territorial. 2008. Memoria Informativa Normal de Conservación Monumento Natural Montańa de Guaza. 42 pp.

Mori, E., Menchetti, M., Camporesi, A., Cavigioli, L., Tabarelli, K. and Girardello, M. 2019. License to kill? Domestic cats affect a wide range of native fauna in a highly biodiverse Mediterranean country. Front. Ecol. Evol., 7: 477.

Nadal, J. 2020. Seguimiento de la población de conejo en Tenerife. Unidad Orgánica de Biodiversidad. Cabildo Insular de Tenerife.

Nogales, M., Martín, A., Delgado, G. and Emmerson, K. 1988. Food sprectum of the feral cat (Felis catus L. 1758) in the juniper woodland on El Hierro (Canary Islands). Bonner zoologische Beiträge, 39: 1-6.

Nogales, M., Abdola, M., Alonso, C. and Quilis, V. 1990. Premiêres données sur l'alimentation du chat haret (Felis catus L., 1758) du Parc National du Teide. Ténérife (Iles Canaries). Mammalia, 54: 189-196.

Nogales, M. and Medina, F. 1996. A review of the diet of feral domestic cats (Felis silvestris f. catus) on the Canary Islands, with new data from the laurel forest of La Gomera. Zeitschrift für Säugertierkunde, 61: 1-6.

Nogales, M., Rodríguez-Luengo, J.L. and Marrero, P. 2006. Ecological effects and distribution of invasive non-native mammals on the Canary Islands. Mammal Rev., 36: 49-65.

Nogales, M. and Medina, F. 2009. Trophic ecology of feral cats (Felis silvestris f. catus) in the main environments of an oceanic archipelago (Canary Islands): An updated approach. Mamm. Biol., 74: 169-181.

Padilla, D., Carmona, J.M. and Martín-Carbajal, J. 2019. Censo de las poblaciones de lagarto gigante de Tenerife (Gallotia intermedia) en el macizo de Teno y la Montańa de Guaza. Cabildo de Tenerife. 72 pp.

Piquet, J.C., Baumgartner, E.S., Medina, F., Díaz-Luis, N., Sevillla, J., López, H., Nogales, M. and LóPEZ-DARIAS, M. 2019. A resource-efficient procedure to improve planning of invasive cat management on inhabited islets. Biol. Invasions, 21: 1817-1831.

Rando, J.C. and López, M. 2001. Actuaciones para la conservación del lagarto canario moteado (Gallotia intermedia). Conserjería de Política Territorial y Medio Ambiente del Gobierno de Canarias. Santa Cruz de Tenerife.

Rando, J.C. 2002. “Gallotia intermedia Hernández et al., 2000. Lagarto canario moteado," in Pleguezuelos, J.M., Márquez, R., Lizana, M., editors. Atlas y Libro Rojo de los Anfibios y Reptiles de España. Madrid, España. Dirección General de Conservación de la NaturalezaAsociación Herpetológica Española pp. 204-206. 
Rando, J.C., Betoret, A., Martín, A. and Barone, R. 2004. Discovery of a new population of the spotted lizard of the Canary Islands. Oryx, 38 (2): 134.

Turner, D.C. and Bateson, P. 2000. The domestic cat: the biology of its behaviour, $2^{\text {nd }}$ edition. Cambridge: Cambridge University Press. 256 pp.

IUCN 2021. The IUCN Red List of Threatened Species. Version 2021-1. <https://www.iucnredlist. org>.

Vigne, J.D., Guilaine, J., Debue, K., Haye, L. and Gérard, P. 2004. Early taming of the cat in Cyprus. Science, 304: 259.

Whittaker, R.J. and Fernández-Palacios, J.M. 2007. Island Biogeography, Ecology, Evolution, and Conservation. Oxford: Oxford University Press. $401 \mathrm{pp}$.

Woinarski, J.C.Z., Murphy, B.P., Legge, S.M. Garnett, S.T., Lawes, M.J., Comer, S., Dickman, C.R., Doherty, T.S., Edwards, G., Nankivell, A., Paton, D., Palmer, R. and Woolley, L.A. 2017. How many birds are killed by cats in Australia? Biol. Conserv., 214: 76-87.

Woinarski, J.C.Z., Murphy, B.P., Palmer, R., Legge, S.M., Dickman, C.R., Doherty, T.S., Edwards, G., Nankivell, A., Read, J.L. and Stokeld, D. 2018. How many reptiles are killed by cats in Australia? Wildl. Res., 45: 247-266.

Woods, M., McDonald, R. and Harris, S. 2003. Predation on wildlife by domestic cats Felis catus in Great Britain. Mamm. Rev., 33: 174-188.

Zavaleta, E.S., Hobbs, R.J. and Mooney, H.A. 2001. Viewing invasive species removal in a wholeecosystem context. Trends. Ecol. Evol., 16: 454-459. 